\title{
Traditional Energy and Renewable Energy: The Differences and Transitions
}

\author{
Guanting Huang ${ }^{1, *},{ }^{*}$, Haoran Wang ${ }^{2, \dagger}$ \\ ${ }^{1}$ Woodbridge High School, Irvine, California, United States \\ ${ }^{2}$ Foreign Languages, Nanjing University of Posts and Telecommunications, Nanjing, Jiangsu Province, China \\ *Corresponding author. Email: 201911031217@mail.bnu.edu.cn \\ These authors contributed equally.
}

\begin{abstract}
With climate change increasingly spreading its negative impact in the world, it is important to do what is needed to resolve this issue. The discovery and application of renewable energy sources have been considered to be an alternative to burning the entirety of fossil fuels and other non-renewable energy sources, e.g. coal, nuclear energy, natural gas. Technology developed for the use of renewable energy sources such as solar energy, wind power, and geothermal energy is relatively new, so the effect of implementing clean energy cannot be determined for certain. First, this paper examines the current traditional and renewable energy industries to demonstrate a realistic understanding of the subject. It shows reasons for transitioning to environmental-friendly energy sources rather than continuing the exploitation of traditional energy. Second, the contrast in governmental attempts to foster the growth of clean energy is examined in the freemarket approach of the United States and the strong government-influenced policies of China. The variability of the effects of different policies is discussed. To eventually succeed in resolving climate change and utilizing renewable energy effectively, global cooperation is crucial.
\end{abstract}

Keywords: global cooperation, energy efficiency, renewable energy

\section{INTRODUCTION}

Traditional energy sources are the most consumed energy sources in the world, including mainly three types of fossil fuels, coal, natural gas, and oil. According to the article "Energy Production and Consumption" published on Our World in Data, the United States's energy use per person was between 75,000 kilowatts per hour and more than 100,000 per hour, putting the United States on the list of the largest energy consumers in the world, including Iceland, Norway, Canada, and wealthy Middle East countries like Oman, Saudi Arabia, and Qatar [1]. The U.S. Energy Information Administration, a division of the U.S. Department of Energy that demonstrates a variety of data about energy production and consumption trends, demonstrated that "more than half of energy use in homes is for heating and air conditioning." Among the energy sources used at home, electricity is used in almost all homes, and retail electricity purchases accounted for $43 \%$ of total residential sector end-use energy consumption in 2020 . Natural gas accounted for $42 \%$ of residential sector end-use energy consumption in 2020 . Petroleum was the next most-consumed energy source in the residential sector in 2020 , accounting for $8 \%$ of total residential sector energy end-use [2]. When they are burned to create electricity or heat, these vastly consumed fossil fuels release carbon dioxide into the atmosphere, gradually raising the overall temperature of the globe as they are burned more often. Limit on the use of carbon dioxide generating energy sources promotes another form of energy source, renewable energy sources. Renewable energy sources are also referred to as green energy because they are naturally replenished. The U.S. Energy Information Administration showed that in 2020, renewable energy provided about 11.59 quadrillion British thermal units (Btu) - 1 quadrillion is the number 1 followed by 15 zeros-equal to $12 \%$ of total U.S. energy consumption. Of the $12 \%$ renewable energy consumption, $39 \%$ came from biomass, $26 \%$ came from wind power, $22 \%$ from hydroelectric, $11 \%$ from solar power, and 3\% from geothermal energy [3]. It can be concluded that biomass, wind, and hydroelectric are the most common replenishable energy sources. 


\section{THE DEVELOPMENT OF ENERGY INDUSTRY}

Although there is a visible increase in the amount of research on recycling energy, the conclusions are general predictions of the effects of implementing new technologies to combat the problem of global warming. Rather than focusing on producing trajectories of future markets of green energy sources, it is necessary to understand why a transition to a healthier energy system is needed. The variability of implementing public policies is crucial to understanding the effects of renewable energy. Energy economics can serve to project a clearer picture of the current state of renewable energy sources. Some researchers try to answer which public policy objectives can be achieved through an increasing deployment of RE technologies. Despite the growing research down in this field, they reveal several white areas that require further research. Countries with abundant energy sources retain energy surplus, thus the implementation of renewable energy has little impact on the overall energy security of the country, which is the uninterrupted energy supply at an affordable price. Thus, renewable energy sources demonstrate their advantage in the environmental benefits. The researchers also state that the claim which states that the implementation of renewable energy sources creates an increase in job opportunities is ambiguous. A potential problem is a bias generated by Integrated Assessment Models, which is a type of modeling that combines the economy with features of the biosphere. The results of the economic potential of renewable energy sources could be biased based on the IAMs because they are not able to take into account the variability of wind and solar. Ultimately, to design suitable public policies for the implementation of renewable energy sources, the impact of different policy instruments like renewable energy subsidies is important for policymakers to consider. The researchers remain optimistic that future studies will continue filling in the gaps [4]. Another group of researchers focuses on comparing the traditional energy sources market to the renewable energy market. The researchers state that the reconstruction of the oil and gas industry improved the technological efficiency of extraction and transportation, which caused a direct decline in oil prices. However, as the profitability of conventional energy sources is growing, the use of renewable energy sources has stagnated. The researchers suggest that the renewable energy industry undergoes a similar process of reconstruction of technological development to ensure the competitiveness of low oil prices. A trend of countries leading in the implementation of renewable energy sources shows that the technologically developed countries in the Research and Development expenditures in the GDP have more influence on the use of renewable energy [5]. The study confirms that the implementation of renewable energy sources is negatively impacted by the continued extraction and consumption of traditional energy sources like oil and natural gas. Regarding the future of energy use, the researchers believe that innovative technology is needed for green energy to serve as a substitute for conventional energy. As of the last decade, renewable energy has shown a relatively great impact on global energy consumption. According to the researchers studying the current status and future aspects of renewable energy technology, global demand for renewable energy increased during 2011 and 2012, supplying an estimated $19 \%$ of global final energy consumption in 2011. Total renewable power capacity worldwide exceeded $1470 \mathrm{GW}$ in 2012, up about $8.5 \%$ from 2011 . Hydropower rose $3 \%$ to an estimated $990 \mathrm{GW}$, while other renewables grew $21.5 \%$ to exceed $480 \mathrm{GW}$. Globally, wind power accounted for about $39 \%$ of the renewable power capacity added in 2012, followed by hydropower and solar PV, each accounting for approximately $26 \%$. In power generation, global wind power capacity grew by $20 \%$ in 2011 (to $238 \mathrm{GW}$ ), after growing by an annual average of $26 \%$ over the five years 2006-2011. Solar PV capacity grew by a record $74 \%$ in 2011 (to $70 \mathrm{GW}$ ), after growing by an average of $58 \%$ over the five years. It can be inferred that renewable energy sources have been substituting for the overall energy consumption at a high speed [6]. Though they do not make up the majority of generated power capacity worldwide, their development has increased dramatically. Regarding the future of the development process of green energy, the researchers believe that the government plays an influential role. It can support renewable energy capacity expansion, create new regulations, and promote technological developments. More importantly, the market's satisfaction with renewable energy sources strongly determines the ability of the renewable energy industry to compete with traditional energy sources.

By studying the structure and setbacks of the nonrenewable energy industry, a fuller understanding of the scope of the need to transition can be demonstrated. On the other hand, renewable energy sources are relatively difficult to judge because of their possibility of growth as a new industry. Different governmental policies in countries vary based on my variables. The effectiveness of the policies is closely associated with the economic development of the country and the methods chosen for the application of clean energy. In the United States, a country that strongly believes in the free market, there are several potential alternatives for the future. A study narrows the method to energy subsidies and the scope to only the ethanol industry in the United States. Energy subsidies are like any other subsidies that are paid to corporations if they follow a certain guideline provided by the federal government. In the methods discussed in the research, four particular methods stand out. The first one is converting a fixed subsidy to one that changes accordingly with the price of oil. The proposed idea is that for any crude oil prices above $\$ 60$ per barrel, no subsidy is delivered. For oil prices between $\$ 40$ and $\$ 60$, 
there is less subsidy than the current subsidy. This can theoretically effectively reduce the incentive to invest in the growth of oil prices. The second approach is to separate the subsidies into two components: one regarding national energy security that is directly tied to energy content and one that is tied to greenhouse gas emission reductions of crude oil. By dividing the subsidy policy into two categories, specific subsidies for various content can be qualified accordingly with the market and subsidies regarding greenhouse gas emission could be regulated more carefully. The third way is to push for an alternative fuel standard instead of subsidies to stimulate growth in production in all alternative fuels. It is assumed that customers will buy alternative energy if it is cheaper than traditional energy. It can also be assumed that the customers will directly purchase the energy pumps instead of paying taxes to the federal government to support subsidies. Lastly, the combination of an alternative fuel standard and a variable subsidy can relieve some weight off the market's shoulders because government subsidies will only start to work when the crude oil prices per barrel fall under $\$ 45$. The federal government could raise the crude oil prices instead of letting the free market create a decreasing pump price [7]. These theoretical policy methods to control the growth of the traditional energy industry and stimulate the development of the renewable energy industry can be more effective if the United States were to adopt a cap and trade climate change policy. The greenhouse gas emissions could be handled through cap and trade and the subsidy policies could handle only the national energy security. Some researchers suggest not energy production subsidies, but research and development subsidies that stabilize the continuous growth of the renewable energy industry. They argue that safeguard measures are the best approaches for the traditional energy industry and workers because they can provide enough time without increasing long-term costs for customers' availability of competitive products [8]. Essentially, they believe that the transfer of technology to less developed countries is crucial in completing the development of the global structure of effective renewables. On the other hand, China stands as a country that is not internationally cooperative in tackling climate change. The uncooperative country's domestic growth still triumphs over environmental issues since it still considers itself a developing country. China's sole political party, the Chinese Communist Party, demands its officials to focus on bringing prosperity to the people because that is how they are evaluated. Although environmental concerns are not the top priority of China, it still addresses environmental issues like controlling carbon emissions because of the social-economic consequences of not doing so. Because of the century-long influence of Western powers in the $1900 \mathrm{~s}$, China is reluctant to act on the demands of Western countries. To avoid continuing counterproductivity in resolving climate change, it is only sensible to begin bilateral projects on renewable energy sources [9]. The contrast between the attitudes of the United States federal government and China's CCP can be extended to a greater scope. Developed countries that have the means to allow the free market to decide the best renewable energy sources can deploy methods like subsidies and other policies to push for change. For developing countries like China, perhaps the only reason to systematically combat climate change is to stabilize the economy. A bilateral view in the global effort in transitioning to renewable energy sources is thus a practical response to climate change.

The energy transition in China may have a different process compared with the situation in other countries due to its unique political system making a fast transition possible. The following evidence and conclusion come from Chinese official media and mainly discuss the relationship between them. The uniqueness of China's political system, Generally speaking, the political situation in China is stable and the Chinese communist party is the one in power. China's current leader $\mathrm{Xi}$ Jinping has the triple titles of General Secretary of the Communist Party of China, Chairman of the Central Military Commission, and President of the State. After assuming these positions in 2012-13, he was reappointed in 2017-18. After the President's term limit was lifted in early 2018 , he will continue to maintain the term limit after the expiration of his current term in 2022-23. Compared with western governments, a longer period between each leading group enables each president to fully concentrate on political affairs without worries of the midterm elections, it will also create a condition where the leading group can have a better environment for cooperation within the group.

A central government is beneficial for the application of regulations because it involves fewer people in the decision-making part, which shortens the time needed to respond to any changes. The continuity of the Chinese government has created a state apparatus that enables policies that may not be profitable for private companies to come to life. After the United Nations Conference on Environment and Development in August 1992, the Chinese government put forward ten major countermeasures for China's environment and development, pointing out that taking the path of sustainable development is an inevitable choice for contemporary China and the future. In March 1994, the Chinese government approved the release of the "China's 21st Century Conference: China's 21st Century Population, Environment and Development White Paper", which, based on the specific national conditions of the population, environment and development, put forward an overall view of China's sustainable development regarding strategies, countermeasures and action plans. Relevant departments and localities have also formulated action plans to implement sustainable development strategies. In March 1996, the "Ninth Five-Year Plan for National Economic and Social Development of the 
People's Republic of China and the Outline of Long-term Goals for 2010" approved by the Fourth Session of the Eighth National People's Congress considered the implementation of sustainable development as the key to modernization. A major strategy that enables sustainable development strategies to be implemented in the process of China's economic construction and social development.

The domestic propaganda of Xi's promotion of Ecological development has formed a motto. It is published and promoted as "ecological environmental protection and economic development are dialectically unified and complementary. Building an ecological civilization and promoting green and low-carbon circular development can not only meet the people's growing need for a beautiful ecological environment, but also promote the realization of higher quality, more efficiency, and more Fair, more sustainable, and safer development, and a civilized development path featuring production development, affluent life, and sound ecology." On April 30 this year, General Secretary Xi Jinping presided over the 29th Politburo of the 19th CPC Central Committee. President xi Emphasized these during the collective studying of the party. On the aspect of environmental protection, a government taking a dominant position will be helpful. At the central level, the decision-makers in China's environmental political system include the Party Central Committee and The State Council and its more than 10 ministries and commissions. As the shaper of environmental political discourse, the Party Central Committees is responsible for formulating macro concepts, discourses, goals, strategies, and guidelines, the National People's Congress and the State Council. The relevant ministries and commissions are responsible for transforming the party's will into specific laws, regulations, and policies through certain laws and policies. Most of the specific policies are formulated by the State Council and its related ministries, but at the same time, They must be supervised by the National People's Congress. The main advantage of the current political system is efficiency. Unlike how things have been operated in many Western countries, the market force has a lighter impact in the market of China. The current transformation of private vehicles using fuelpowered cars to electric cars makes the best examples of this. First, the proportion of personal consumption of new energy vehicles has risen sharply to nearly $70 \%$, compared with only $20 \%$ two years ago. Second, the proportion of non-restricted purchases in cities has reached $60 \%$ of all purchases. These market driving factors indicate that are increasingly accepting new energy vehicles, and the personal market will increase greatly in the future. Moreover, the country's new energy vehicle models are widely distributed, covering high, middle, and low end, which can meet the diversified needs of the consumer market. At the recent media communication meeting held by the Ministry of Industry and Information Technology, Ye Shengji, deputy secretary-general of the China Association of Automobile Manufacturers, said that the sales of new energy vehicles this year have exceeded expectations and are expected to reach 1.3 million vehicles, an increase of nearly $8 \%$. It is even a greater surprise in 2021. In August, China's automobile production and sales reached 1.725 million and 1.799 million respectively. From January to August, the production and sales of automobiles were 16.166 million and 16.556 million, a year-on-year increase of $11.9 \%$ and $13.7 \%$.

In August, the new energy vehicle market still outperformed the market, with production and sales reaching 309,000 and 321,000 respectively, an increase of $8.8 \%$ and $18.6 \%$ month-on-month, and a year-on-year increase of 1.8 times. Among the main types of new energy vehicles, the production and sales of pure electric and plug-in hybrid vehicles have increased compared with the previous month, and the sales growth of pure electric vehicles has been more obvious. From January to August, the production and sales of new energy vehicles reached 1.813 million and 1.799 million, respectively, a year-on-year increase of 1.9 times. Among the main types of new energy vehicles, the production and sales of pure electric and plug-in hybrid vehicles have continued to grow rapidly compared with the same period last year. The country's new energy vehicle sales growth rate is likely to exceed $30 \%$, reaching 1.8 million vehicles. It's hard to believe that all these have been made within 3 years.

\section{THE U.S. PLAN FOR FUTURE ENERGY INDUSTRY}

At a ceremony held by the US Environmental Protection Agency in 2017, Trump signed an executive order called "Energy Independence", instructing the agency to begin legal procedures to revoke and rewrite the "Clean Power Plan." This plan was the whole point of Obama's policy to prevent global warming. Trump claimed that this change will decrease the dependency on imported energy (fuels) and boost the traditional coal energy. However, energy economists claim that this order does not achieve these two goals partly because the United States already relies heavily on domestic coal and natural gas, and most American power plants use them. "We don't import coal," said Robert N. Stavins, an energy economist at Harvard University. "So from the perspective of a clean energy plan, this has nothing to do with energy independence. Robert W. Godby, the energy economist of Wyoming University, said that the new command will mean old age. But even so, "The mine that is still operated is also mechanized," he said. "They don't hire people, so even if we see that coal production increases, the coal work will still be reduced." This may cause domestic strikes, hence falling productivity because people may start doubting the purpose of the 
policy, believing that this will benefit the enterprises of the industry and cause a class contradiction. Fortunately, things have been different when Biden became the president. Biden takes the Green New Deal as the key framework for addressing climate challenges, focusing on "energy technology innovation and application", "climate-friendly and adaptive infrastructure construction and transformation", "climate diplomacy and U.S. leadership in global climate governance". The four main aspects of fairness and justice in environmental and climate governance have put forward the "Clean Energy Revolution and Environmental Justice Plan". He intends to use the issue of climate change to set off a revolution in the United States and even the world, to revive the United States' global leadership in the development of climate change, climate governance, clean energy technology, manufacturing, and energy industries.

It is an undeniable fact that the new policy will take America to a greener country but the waving attitude of the US government might find it hard to request international cooperation and fundings because it's hard to predict the future position of the government in the next election year. From the perspective of China, it is sensible to say that the energy transition process will be faster than most countries in the globe because one of the major advantages of the delete of public election saves time and this will create a more trustworthy illusion of the Chinese government so there will be more opportunities for cooperation hence the government could fully concentrate on the environmental protection plan with no need for too many concerns of the election this will bring

\section{CONCLUSION}

In conclusion, the energy transition is a major trend of the modern world because of its widespread usages in people's lives and its irreplaceability that has caused contractions with the cost of mankind using it. Certainly, the pollution produced by traditional fuels cannot be ignored in the current environment where an increasing number of people are paying attention to the environmental protection process. Researchers and officials in the globe are all dragged into this topic and there are points of contrast made by professionals in different countries but the main purpose of most of them are the same, that is to find a long term solution for the human beings to live on with sustainable energy resources. Hence the article mainly discusses the differences in the energy transition in China and how it might be different in comparison with the situation in western countries. As the article has provided a series of evidence of the necessity of altering energy, the process is inevitable and unpreventable for all the countries in the globe.

\section{REFERENCES}

[1] Ritchie, Hannah. "Energy Production and Consumption." Our World in Data, 28 Nov. 2020, ourworldindata.org/energy-productionconsumption.

[2] "Use of Energy in Homes - U.S. Energy Information Administration (EIA)." U.S. Energy Information Administration 2020 , www.eia.gov/energyexplained/use-ofenergy/homes.php.

[3] "Renewable Energy Explained - U.S. Energy Information Administration (EIA)." U.S. Energy Information Administration, 2020, www.eia.gov/energyexplained/renewable-sources.

[4] Edenhofer, O, Hirth, L, Knopf, B, Pahle, M, Schlomer, S, Schmid, Eva \& Ueckerft 2013, 'On the economics of renewable energy sources', Elsevier

[5] Eder L.V., Provornaya I.V., Filimonova I.V., Kozhevin V.D. \& Komarova A.V. 2018, 'World energy market in the conditions of low oil prices, the role of renewable energy sources', Elsevier

[6] Ellabban, O, Abu-Rub, H \& Blaabjerg, F 2014, 'Renewable energy sources: Current status, future prospects and their enabling technology', Elsevier

[7] Tyner E. W \& Taheripour F 2007, 'Renewable Energy Policy Alternatives for the Future', American Journal of Agricultural Economics, vol. 89, no. 5, pp. 1303-1310

[8] Cottier Thomas 2014, 'Renewable Energy and WTO Law: More Policy Space or Enhanced Disciplines?', Renewable Energy Law and Policy Review, vol. 5, no. 1 , pp. $40-51$

[9] Ong H. L 2012, 'The Apparent 'Paradox' in China's Climate Policies: Weak International Commitment Emissions Reduction and Aggressive Renewable Energy Policy', Asian Survey, vol. 52, no. 6, pp. $1138-1160$

[10] A statement from the Chinese government, department of the ecology, retrieved from www.mee.gov.cn/ywdt/szyw/202006/t20200605_7 83073.shtml.

[11] An industrial guided report on American Environmental Protection strategy, retrieved from https://www.google.com/url?sa=t\&source=web\&rc $\mathrm{t}=\mathrm{j} \& u r l=h \mathrm{ttp}: / / \mathrm{www}$.istis.sh.cn/list/list.aspx\%3Fid \%3D2933\&ved=2ahUKEwj42Mq3kOLzAhXxwos BHWXaB50QFnoECAUQAQ\&usg=AOvVaw1ou WZnFrxwQ512juEIbFCB 
[12] A report from American Environmental Protection Association , retrieved from https://www.google.com/url?sa=t\&source=web\&rc $\mathrm{t}=\mathrm{j} \& u r l=h t \mathrm{tp}: / / \mathrm{www} . \mathrm{w}$.net.cn/m/about.php\%3Fid \%3D2\&ved=2ahUKEwj42Mq3kOLzAhXxwosBH WXaB50QFnoECAcQAQ\&usg=AOvVaw0_ilccK V5mWePp7q_b70ZH

[13] An industrial report from Chinese renewable energy mobile car, retrieved fromhttps://www.google.com/url?sa=t\&source=we b\&rct=j\&url=https://data.eastmoney.com/report/zw _industry.jshtml\%3Finfocode\%3DAP2021082315 $11873281 \&$ ved=2ahUKEwjfqM_OrLzAhWFbN4KHQmJBDoQFnoECAUQAQ\&usg= AOvVaw3ny5bjQEM5uUw1SqQbX51_ 